\title{
The Introduction of ICTs in Chilean Schools - An Analysis of the Various Initiatives since Enlaces and the Issues Faced by the Mapuche
}

\author{
Fernando Toro \\ ICT Consultant \\ c-fernandot@hotmail.com
}

\begin{abstract}
The Introduction of ICTs in Chilean Schools - The Various Initiatives since Enlaces and the Issues Faced by Mapuche Students
\end{abstract}

Keywords: Information and Communication Technology (ICTs) Education, History of Computers in Chilean Schools, Chile, Education, Educational Policy, Mapuche, Inclusion, Social Capital.

\section{Background}

The use of Information and Communication Technologies (ICT) in education has for long time now, generated extensive interest as well as being attributed to have an important role in education. Prior to 1990, Chile had a minimal exposure to ICTs in education and thus with the return to democracy the country was also interested in the role that ICTs could have in education. Therefore, it embarked on a major initiative to introduce ICTs in schools and reform the education system. It must be noted that the reforms were implemented on the foundations of a free market model imposed by the previous dictatorial Pinochet regime and the many reforms that have taken place have not been without social and political challenges. This journey of reforms started in 1992 with the birth of 'Programa Enlaces' or 'Enlaces' for short, a pilot program that was first implemented in a small number of school in the capital, Santiago and was later expanded to include the region of Araucania. This region has the highest proportion of Mapuche people, as compared to other regions in Chile, in fact, over $30 \%$ of its inhabitants consider themselves Mapuche. It is also one of the poorest regions in the country. The Mapuche are the indigenous people of the south of Chile and Argentina.

Enlaces was primarily an educational web that connected schools and provided access to ICTs. Enlaces expanded quickly and by 1995 the program expanded quickly, managing to connect 5,300 schools. By 2000, Enlaces was expanded and managed to connect the totality of rural school in the country and by 2014 that totality of subsided schools were connected. Enlaces was also enhanced by other initiatives that placed more ICTs in the classroom, introduced teacher training in the use of ICTS, connected rural school with improved bandwidth, increased the number of 
students scholarships that provided free laptops or computers, the creation of software and portals.

The newly elected government had identified that Chile's education system had structural deficiencies, poor performance results, impoverished schools and lacking in quality and equity. Thus, ICTs were seen as tools that would enrich the students' education and ultimately provide a better quality of education under a more egalitarian system. The broader reforms were centred on the regulatory frameworks, changes to curriculum (to both, primary and secondary levels), teacher training and development, increasing pedagogical resources and infrastructure for schools, improving students' attendance and increasing the time spent on teaching. However, the introduction of ICT into the education system has not been without challenges and/or criticism. For example, although there have been marginal quantifiable results that would attest to the rationale behind these measures, there is still a significant number who believe that the changes have not been sufficient or go deep enough to remove any vestige from the reforms implemented during the military dictatorship that ruled from 1973 to 1990 . The political climate in Chile remains polarised and so, the subject of education has become politicised. Parents, students and teachers have all had an interest in the education system. As a result, educational reform, has been a controversial political problem during the various governments since the return of democracy.

Despite the various initiatives implemented, the approach for the greater part often assumed a homogenous population and very much a top-down, 'one-size-fits-all' approach. These strategies may be fit-for-purpose in some circumstances, for example, the private sector and industry specific. However, the traditional Mapuche concept of building knowledge is through what they call "to learn by doing" which takes the form in labor, social, cultural and productive actions that Mapuche people developed, in which the teaching - learning process involved different family members, where the main methodological aspect was centered in communication. Therefore, a homogenous, blanket approach may not be suitable for a group where the main approach is more collective and inclusive. As indicated earlier, the Mapuche, live in a region with a high poverty index and with its inherited issues related to the lack of inclusion and literacy rates, therefore, education needs to be looked at a level that consults and includes the community. So, that it is the community that becomes empowered to recognise and confront their concerns within the contexts of their own culture. On the contrary, the Mapuche will continue experiencing a dilution of their culture either by adaption, tacit imposition or adoption of the values imparted by the state through the educational context of schools. This not only includes the curriculum content but also the physical structures, government policies, technology, social inclusion and social capital.

\section{Introduction}

The use of Information and Communication Technologies (ICT) in education has generated widespread interest as well as being attributed to have an important role in 
education [1-9]. Of course, in this day and age, the introduction of ICTs in education is not a new concept given that we are now on the path of a fourth Industrial Revolution, also referred to as the 'digital revolution' [10], which is building on the third and is distinguished by the fusion of technologies and thus the lines between the physical, digital and biological are becoming unclear and as such, also affect governments, skills and labour, business and economies alike [11, 12].

Prior to the 1990, Chile had no public policy which included ICTs in the education of its students. However, changes and policy where quickly implemented once democracy was restored and one of the major changes was the birth of Enlaces, which started as pilot program to connect a small number of school in the capital Santiago and was later expanded to include a small number of schools in regional capital Temuco located in the region of Araucania.

\section{$3 \quad$ Return to Democracy and the Birth of Enlaces}

Mr Patricio Alwyn, became the first president of Chile (from 1990 to 1994) after the Pinochet dictatorship had ended and democracy was once again restored [13]. Prior to 1990, Chile had no public policy to promote the use of ICTs in education and its exposure in this area was limited [14]. Although, there was a small number of schools which either had computers or a lab; these were mainly secondary schools where the aim was to teach programming, for example, Basic or Logo (Jara 2013). At the academic level, Jara [15] indicates that there was an incipient and interested community on this theme. However, in March 1990 the 'Programa de Mejoramiento de la Calidad y Equidad de la Educación Básica' programme (usually referred to as 'MECE Basica') was devised [14, 16]. With finance and advice from the World Bank, the initiate got underway in 1992 and so, the country embarked on a national initiative to improve the education system [17], starting at the primary education level with the aim to improve quality, equity and efficiency [18]; at the preschool aiming to expand the coverage and enhance the quality of education at this level and finally, to develop institutional, managerial and financial capacity at the basic education system [18] and which later included the implementation of ICTs in schools [Bellei 17, 19, 20].

There was, to some degree, a consensus that as a result of the challenges posed by the how to, form, educate, teach, learn in a world where information is the central element of productivity, where individual and collective opportunities are played out within the networks that are accessible [21], President Alwyn's newly elected government wanted to respond to these challenges and 1992 saw the creation of 'Programa Enlaces', often referred to 'Red Enlaces' or only as 'Enlaces', which was born within the MECE Basica initiative ('Linkages Program' in English) [3, Toro 16, 19, 20, 22, 23]. Notwithstanding, the conceived changes were to be implemented on the foundations of the neo-liberal market model imposed by the previous dictatorial regime [24]. Successive governments have been criticised for failing to reform the inherited aspects of the education system [25]. Subsequent coalition governments that proceeded Mr Alwyn's presidency, as well as students, parents and teachers; all had an interest in the education system. As a result and due to the various actors involved, 
educational reform has been a contentious political issue in the country [26]. On the one hand, the majority of students, parents and a significant part of the electorate, claim that education should be free of charge, not for profit, of good quality and inclusive [27]. They argued that the market model and is geared to the generation of profits as opposed to providing education, as the main tenet, persisted beyond the Pinochet regime and has continued to some degree, during the various democratic governments that followed [28]. Therefore, the country was rocked by major student protests in 2006, the so called 'pinguino' protests during which approximately 600,000 marched demanding educational reforms $[17,25,29]$ and students protest have persisted throughout 2008, 2011, 2012, 2015, 2016 and 2018 [27, 29, 30].

The 'Enlaces' program was developed as an experimental initiative to implement computer technology in schools [20,22]. Changes were required due to the failures of the inherited education system which had been through a period of decentralisation and privatisation during the Pinochet dictatorship [26, 29, 31, 32]. For example, as described by Sánchez and Salinas [20], Claro, Preiss, et al. [22] and Toro [32], there was also a need to improve the quality and equity in education in publicly financed education in Chile. Thus, 'Enlaces' was broadly seen as part of the national consensus and urgent need for more equity and quality in the Chilean education [20]. The inception of Enlaces was not straight forward as the then Minister of Education, $\mathrm{Mr}$ Ricardo Lagos had to contend with two main approaches, each with their pros and cons [16]. One approach intended to follow a similar path as taken by Costa Rica, with emphasis on the learning of specific programming languages and requiring massification which would require a high number of computers installed throughout the country $[14,16]$. According to Toro (2010) this approach was met with questions on acceptance, adoption, quantifiable result and obsolescence. Notwithstanding, this was a highly visible approach politically, but it was not adopted. Therefore, a second proposition was considered, one that was much less visible politically but which has been in the long term generally seen as a public policy in which the state has been the biggest promoter of technological innovation [17]. The latter was Enlaces, a pilot program with a much smaller presence and that would lay the foundations for a much bigger future project (Jara 2013); initially, it connected only six schools in Santiago within the vicinity of the Universidad Católica’s San Joaquin Campus (Toro 2010) and subsequently, connected a further fifteen more schools in Temuco (Toro 2010), which is about 700 kilometres to the south of Santiago in the Araucania regions (Toro 2018). Despite the small beginnings, Enlaces expanded quickly and defying expectations, by 1995 a total of 5,300 schools (ranging from primary to secondary levels) had been connected [33]. However, the majority of rural schools had to wait another 5 years to start connecting to Enlaces (Jara 2013, Enlaces 2019). In 1996 an alliance was formed between the Ministry of Education and the universities along the entire county [33], this was known as the 'Red de Asistencia Tecnica de Enlaces' but usually referred by its initial as RATE [14]. The aim of RATE was to support the primary and secondary school that were part or pending connection to Enlaces, becoming an integral component to the expansion of Enlaces throughout the country $[14,16]$. Initially, this alliance comprised 6 universities and expanded to 24, out of which 7 had a leading role in the implementation of Enlaces to the rest of the schools 
in the country (Jara 2013). The universities which were part of RATE were involved in providing the school teachers with ICT training, provide technical support, provide email services and to keep up with the growing demand due to the rapid expansion, the universities organised a network of about 1000 trainers who were usually school teachers who originated from the schools already connected and who served as Enlaces coordinators who helped to create a nexus between the school and university frameworks [14, 16, 33, 34]. In 1998, the educational reform officially incorporated the Information Technology as a curriculum subject for high schools, as well as the provision of CDs which contained education resources, such as software, catalogues and search engines [33]. Most importantly, the Internet arrives free of charge to the schools with the aide of the private enterprises such as Telefonica CTC Chile (Enlaces 2019). The year 2000 marks an important point for Enlaces due to its expansion of coverage which would connect rural and remote schools [33, 34]. In 2002, Enlaces is recognised with an equity award at the Second Information Technology in Education (SITE) conference held in Nashville, U.S.A. for increasing the digital equity and the renovation of education through the use of ICTs (Enlaces 2019). During this period teachers were also situated at the vanguard of the integration process (Enlaces 2019). during 2003 and 2004, there were further resources made available such as digital classes, refurbished computers placed in classrooms (approximately 30 students per computer), improving the performance in Mathematics using ICTs, but most importantly, bringing Internet access to remote areas where there was none (Enlaces 2019). from 2005 to 2011 there was a continuation of innovative measures for the education such as the use of Linux to take advantage of open source applications and prolonging the life of some older computers, whilst at the same time, acquiring more equipment to provide quality education and the introduction of Mobile Computer Labs (Enlaces 2019) but more importantly, this period also saw the collection of data to measure the penetration of ICTs and their use in the classroom and in 2010 obtained the ISO 9901-2008 quality certification (Enlaces 2019). During the period from 2012 to 2015 more initiatives were introduced that included the use of ICTs, one of these was known as 'TIC y Diversidad' (in english, ICT and Diversity) and which included teaching math, science and history to students with hearing impairment, in fact, by 2014 the totality of school catering for students with special audio needs where covered by this program (Enlaces 2019). The use of tablets as teaching and learning tools by preschoolers was also launched (Enlaces 2019). Furthermore, in 2014, the data gathered in previous years indicated that $46.9 \%$ of students were at a proficiency level of beginners, 51.3\% were at intermediate level and 1.8 at an advanced level, these figures covered students at school all levels (Enlaces 2019). From 2015 onwards, a number of scholarship programs were established to benefit students who were classified as lacking resources or from a low socio-economic status and enrolled in a subsidized school, namely, the 'I Choose my PC' Scholarship (in Spanish, 'Yo Elijo Mi PC') and 'I Connect to Learn' (in Spanish, 'Me Conecto Para Aprender') were established (Enlaces 2019). During 2015 and through the 'Yo Elijo Mi PC' scholarship, 70,000 students benefited under this scholarship. According to figures provided by Junta Nacional de Auxilio Escolar y Becas [35], since its inception, 350,000 students have benefited as a result of the scholarships and an extra 
30,000 who are enrolled in a subsidized school in grade seven were expected to benefit in 2017 [36] and by 2019 about 130,000 students would be able to receive a computer [37].

\section{The Situation of the Mapuche - Some Key Factors}

The region of Araucania has the highest proportion of Mapuche people, as compared to other regions in Chile and over $30 \%$ of its inhabitants consider themselves Mapuche. It is also one of the poorest regions in the country [38, 39]. This figure rises higher when we look at the communes within Araucania. For example, in the communes of Saavedra, Cholchol, Galvarino and Freire, the rate of poverty is about $60 \%$ and with just over $67 \%$ of this group living in rural areas [39, 40].

Valenzuela, Toro at al [39] indicate that there has been little effort towards profiling the Araucania region socio-economically. However, Cerda [40] as referenced by Valenzuela, Toro at al (2017) provides one of the better known studies on the subject. Furthermore, Cerda [40] has concluded that the region, having high levels of poverty and unemployment, as well as low levels of schooling, has resulted in low level of growth. However, as indicated by Valenzuela, Toro at al (2017), this phenomenon is not isolated to the Mapuche or ethnicity and affects all social sectors. In fact, the region has the highest proportion of poor people of Chile and it is the 'third region with the greatest number of people in poverty, with 217,755 people living beneath the poverty line' [39].

\section{CASEN - The Socioeconomic Characterisation Survey}

CASEN is the short name for 'National Survey of Socioeconomic Characterisation' (in Spanish: 'Encuesta de Caracterización Socioeconómica Nacional'), which has been under the guidance of the Ministry of Social Development and has been carried since 1990 and approximately, every two years, thus, 1992, 1994, 1996, 1998, 2000, 2003, 2006, 2009, 2011, 2013 and 2105 [41]. According to the Ministerio de Desarrollo Social [41], the aim of the survey is to periodically understand the situation of the population, with a focus on those that are in a state of poverty. It also looks at education, income, health, housing and jobs. In addition, the survey is a means by which the government can evaluate the impact of fiscal expenditure on the relevant areas the survey targets and social programs that are also targeting these areas [41].

\section{The Data from CASEN 2015 - Indigenous People}

On July 2017, the Chilean Ministry of Social Development published the CASEN 2015 results centred on the indigenous people in Chile [42]. The results were comprehensive and provided some very relevant data that contextualises with the 
theme of this thesis. Therefore, the following section provides some of the data provided by CASEN 2015.

From the total population in Chile who identify as indigenous over the time period from 2009 to 2015, the following percentage of population belonging to an Indigenous People were recorded:

Year /Percentage:

$2006-6.6$

$2009-6.9$

$2011-8.1$

$2013-9.1$

$2015-9.0$

Adapted from [42]

\section{$7 \quad$ Language - Mapudungun}

The language spoken by the Mapuche is the Mapudungun [43, 44]. The Mapuche in Chile have been facing a number of challenges in retaining their language. The number of younger Mapuche who speak the language has been decreasing and thus, only older generations are still retaining the language. Data from CASEN 2015 [42], provides details on the knowledge and use of the Indigenous languages in the country. Thus, data from 2009 to 2015 indicated that those who speak and understand their language fell from $12.0 \%$ to $10.7 \%$. Those who only understand, remained somewhat steady from $10.6 \%$ to $10.7 \%$. Those who neither speak or understand increased from $77.3 \%$ to $78.6 \%$ [42]. These figures demonstrate that there is a greater number of indigenous people who neither speak nor understand their language and appear to become more apparent in the younger generation as seen on figure 1.0 below where the younger generation is struggling to speak and understand:

Table 1. - Percentage of Indigenous People and Language Command by Age Group (Adapted from [42])

\begin{tabular}{|c|r|r|r|}
\hline $\begin{array}{c}\text { Age Group } \\
\text { (in years) }\end{array}$ & $\begin{array}{c}\text { Speaks and } \\
\text { Understands }\end{array}$ & $\begin{array}{c}\text { Only } \\
\text { Understands }\end{array}$ & $\begin{array}{c}\text { Neither Speaks or } \\
\text { Understands }\end{array}$ \\
\hline 0 to 14 & 5.0 & 6.4 & 88.6 \\
\hline 15 to 29 & 7.1 & 10.3 & 82.6 \\
\hline 30 to 44 & 12.4 & 13.6 & 74.1 \\
\hline 45 to 59 & 14.2 & 13.9 & 71.9 \\
\hline 60 or more & 24.9 & 13.1 & 62.0 \\
\hline
\end{tabular}

According Sotomayor, Allende et al [45] the Ministry of Education claimed in 2013 that 472 schools had implemented an indigenous language subject. Sotomayor, 
Allende et al [45] also indicate that the Araucania region is where the majority of schools have included Mapudungun as a subject, that is, 220 (54\%) schools. Moreover, Sotomayor, Allende et al [45] argue that students attending these school belong to a low socioeconomic level and that the average level of education attained by their parents is 9 years of schooling. Moreover and with reference to educating Mapuche children, Quintriqueo and Torres [46] indicate that historically this has been on a system, content and outcomes based on an Occidental model and so it fails to consider the traditional Mapuche concept of building knowledge through what they call "to learn by doing" which takes the form in labor, social, cultural and productive actions that Mapuche people developed, in which the teaching - learning process involves different family members, where the main methodological aspect is centered in communication and so, the various programs, by default, assume a neutral sociopolitical framework, that is representative of the general and homogenous education system that is inserted and directed by the state [47] and which also contains the rules, structure, values and measures imposed by the Chilean state [48]. Therefore, this centralised approach bypasses and denies visibility to the local social processes which are integral to the dynamic culture and organisation as it serves only those aspects of indigenous education and culture that are pertinent and functional to the centralised content and which has been historically based on an occidental perspective, leaving a gap between the western and Mapuche context [47, 49, 50].

\section{Conclusion}

The democratic governments followed after the dictatorship, became aware of the challenges being faced by the education system and envisaged an innovative and large plan to improve the education system, bring about some reform and make the education more equitable. This led to the the MECE program from which Enlaces was born. Enlaces has contributed in introducing ICTs into Chilean schools and has achieved practically universal coverage. Aside from the introduction of ICTs, since the return of democracy, governments have faced many challenges due the inherited education system. There have been many student and parents protests clamouring for free, equitable and quality education.

On the other hand, changes made to the education systems, such as Enlaces, have been homogenous and blanketed approaches which not be suitable for a group where the main approach is more collective and inclusive, as the Mapuche, who live in a region with a high poverty index and with its inherited issues related to the lack of inclusion and literacy rates, loss of culture and language. Therefore, education needs to be looked at a level that consults and includes the community. So, that it is the community that becomes empowered to recognise and confront their concerns within the contexts of their own culture. On the contrary, the Mapuche will continue experiencing a dilution of their culture either by adaption, tacit imposition or adoption of the values imparted by the state through the educational context of schools. This not only includes the curriculum content but also the physical structures, government policies, technology, social inclusion and social capital. 


\section{References}

1. Borja, R. Asia - The divide between the digital haves and have-nots is as wide as the region itself. Education Week, 2004. 23, 24.

2. Enlaces. TICs en Aula. [Online] 2009a [cited 2009 20/03/2009]; Available from: http://www.enlaces.cl/index.php?t=44\&i=2\&cc=170\&tm=2.

3. Enlaces. Nuestra Historia. [Online] 2009b [cited 2009 20/03/2009]; Available from: http://www.enlaces.cl/index.php?t=44\&i=2\&cc=170\&tm=2.

4. Enlaces. ¿Quiénes Somos? [Online] 2009f [cited 2009 20/03/2009]; Available from: http://www.enlaces.cl/index.php?t=44\&i=2\&cc=170\&tm=2.

5. Fry, G.W., The interface between experiential learning and the Internet - Ways for improving learning productivity; in On the Horizon. 2002, MCB UP Limited. p. 5-11.

6. Granger, A., et al., Factors Contributing tp Teachers' Successful Implementation of IT Journal of Computer Assisted Learning, 2002. 18(4): p. 480-488.

7. Lan, J. Web-Based Instruction for Education Faculty: A needs Assessment. Journal of Research on Computing in Education, 2001. 33, 15.

8. Newton, L., Visscher, A.J. Management Systems in the Classroom, Management of education in the information age: the role of ICT,. in Fifth Working Conference on Information Technology in Educational Management (ITEM 2002), IFIP TC 3/WG 3.7. 2003. Helsinki, Finland: Kluwer Academic Publishers.

9. Twining, P., The Computer Practice Framework: a tool to enhance curriculum development relating to ICT', in ICT for curriculum enhancement., $\mathrm{M}$. Monteith, Editor. 2004, Bristol: Intellect: UK.

10. Schäfer, M., The fourth industrial revolution: How the EU can lead it. European View, 2018. 17(1): p. 5-12.

11. Schwab, K. Fourth Industrial Revolution - Will the Fourth Industrial Revolution have a human heart? 2015201829 Aug 2018]; Available from: https://www.weforum.org/agenda/2015/10/will-the-fourth-industrial-revolutionhave-a-human-heart-and-soul.

12. Schwab, K. Fourth Industrial Revolution - The Fourth Industrial Revolution: what it means, how to respond. 2016201829 Aug 2018]; Available from: https:/www.weforum.org/agenda/2016/01/the-fourth-industrial-revolutionwhat-it-means-and-how-to-respond/.

13. Bauer, P. Patricio Aylwin. [Online] 201717 Mar 201727 Nov 2017]; Available from: https://www.britannica.com/biography/Patricio-Aylwin.

14. Jara, I., Las políticas TIC en los sistemas educativos de América Latina: CASO CHILE. Programa TIC y Educación Básica, ed. E. Duro. 2013, Argentina: UNICEF. 61.

15. UNICEF Argentina and I. Jara, Las políticas TIC en los sistemas educativos de América Latina: CASO CHILE. 1 ed. Vol. 2. 2013, Argentina: UNICEF Argentina. 60.

16. Toro, P., Enlaces: Contexto, historia y memoria, in El Libro Abierto de la Informática Educativa: Lecciones y Desafíos de la Red Enlaces, A. Bilbao and 
A. Salinas, Editors. 2010, Enlaces, Centro de Educación y Tecnología del Ministerio de Educación: Chile. p. 37 - 50.

17. Bellei, C., Evolución de las políticas educacionales en Chile (1980-2009), in El Libro Abierto de la Informática Educativa: Lecciones y Desafíos de la Red Enlaces, A. Bilbao and A. Salinas, Editors. 2010, Enlaces, Centro de Educación y Tecnología del Ministerio de Educación: Chile. p. 14 - 36.

18. Holm-Nielsen, L., K. Thorn, and J. Juan Prawda Chile - Decades of Educational Reform Deliver. En Breve, 2004. 4, 1-4.

19. Silva, L. and E. Figueroa, Institutional intervention and the expansion of ICTs in Latin America. Information Technology \& People, 2002. 15(1): p. 8-25.

20. Sánchez, J. and A. Salinas, ICT \& learning in Chilean schools: Lessons learned. Computers \& Education, 2008. 51(4): p. 1621-1633.

21. Bilbao, A. and A. Salinas, La informática educativa en Chile, 17 años después, in El Libro Abierto de la Informática Educativa: Lecciones y Desafíos de la Red Enlaces, A. Bilbao and A. Salinas, Editors. 2010, Enlaces, Centro de Educación y Tecnología del Ministerio de Educación: Chile. p. 7 - 11.

22. Claro, M., et al., Assessment of 21st century ICT skills in Chile: Test design and results from high school level students. Computers \& Education, 2012. 59(3): p. 1042-1053.

23. Toro, F. and A. Tatnall, Developing a Project to Investigate the Introduction of ICT to Mapuche Students in Chile. International Journal of Actor-Network Theory and Technological Innovation (IJANTTI), 2016. 8(1): p. 34-43.

24. Brunner, J.J., Comparative research and public policy: from authoritarianism to democracy. Peabody Journal of Education, 2005. 80(1): p. 100-106.

25. Walsh, A., The Legacy of Dictatorship and Persistent Socio-Economic Inequalities in Chile’s Educational Policy. Aigne Journal, 2018. 4(2): p. 25.

26. Planas, R. Chile's Piñera Takes on Education Reform. 2011.

27. Martínez, E.G. and R.Z. Farías, Formas de inclusión-exclusión en el sistema educativo chileno: el movimiento estudiantil secundario 2006-2011. Revista Brasileira de Educação, 2018. 23: p. 23.

28. Cabalin, C., Neoliberal Education and Student Movements in Chile: Inequalities and Malaise. Policy Futures in Education, 2012. 10(2): p. 219-228.

29. Toro, F., Impacts of Computer Technology by Mapuche Students in Chilean Schools, in College of Business. 2018, Victoria University: Australia. p. 283.

30. Schwabe, N., "No somos hijos de la democracia, sino nietos de la dictadura": El movimiento estudiantil chileno en 2011 y después, in Nueva Sociedad. 2018, Nueva Sociedad: Argentina. p. 98-109.

31. Sánchez, J., Á. Salinas, and J. Harris, Education with ICT in South Korea and Chile. International Journal of Educational Development, 2011. 31(2): p. 126148.

32. Toro, F., Experiences as a Student in Chile with Only Pre-computer Technologies, in Reflections on the History of Computers in Education: Early Use of Computers and Teaching About Computing in Schools., A. Tatnall and B. Davey, Editors. 2014, Springer: Heidelberg. p. X, 423 pages. 
33. Enlaces. Historia. [Online] 20198 Feb 2019]; Available from: http://www.enlaces.cl/sobre-enlaces/historia/.

34. Hinostroza, E., P. Hepp, and C. Cox, National Policies and Practices on ICT in Education - Chile (Enlaces), in Cross-National Information and Communication Technology: Policies and Practices in Education, T.A. Plomp, Ronald; Law, Nancy; Quale, Andreas, Editor. 2009, IAP-Information Age Pub. p. 157 - 170.

35. Junta Nacional de Auxilio Escolar y Becas. ¿Qué es Yo Elijo mi PC? 2017 [cited $2017 \quad 24$ Aug 2017]; Available from: http://www.yoelijomipc.cl/index.php/que-es-yo-elijo-mi-pc/.

36. Ministerio de Educación. Me Conecto para Aprender. 20172017 [cited 201724 Aug 2017]; Available from: http://meconecto.mineduc.cl.

37. Ministerio de Educación. Junaeb extendió el plazo para que estudiantes que pasan a $7^{\circ}$ básico elijan sus computadores. 20192019 [cited 20178 Feb 2019]; Available from: http://meconecto.mineduc.cl/2019/01/02/junaeb-extendio-elplazo-para-que-estudiantes-que-pasan-a-7o-basico-elijan-sus-computadores/.

38. Aylwin, J., Politica Publicas y Pueblos Indígenas: El Caso de la Politica de Tierras Del Estado Chileno y el Pueblo Mapuche. . 2002, Universidad de la Frontera: Chile. p. 42.

39. Valenzuela, M.S., S.Y. Toro, and F. Rojo-Mendoza, Equal in Poverty, Unequal in Wealth: Ethnic Stratification in Chile, the Mapuche Case. Bulletin of Latin American Research, 2017. 36(4): p. 526-541.

40. Cerda, R. Situación socioeconómica reciente de los mapuches en la región de la Araucanía’. Revista de Estudios Públicos, 2009. 27-107.

41. Ministerio de Desarrollo Social Archivo histórico de Encuesta CASEN. 201730 Nov 2017]; Available from: http://observatorio.ministeriodesarrollosocial.gob.cl/casen/casen_obj.php.

42. Ministerio de Desarrollo Social - Subsecretaría de Evaluación Social, CASEN 2015 - Pueblos Indigenas - Síntesis de Resultados, in CASEN 2015. 2017, Ministerio de Desarrollo Social - Subsecretaría de Evaluación Social Chile. p. 129.

43. Garrido, R., F. Martinez, and I.M. Solano, Las TIC en las comunidades Mapuches: Un proyecto de integración de las TIC para el desarrollo social de pueblos originarios, in PRENDES, M.P. Tecnologías, desarrollo universitario y pluralidad cultural. 2011, Alcoy: Marfil. p. 101-117.

44. Wikipedia contributors. Mapuche language. 201724 November 201730 Nov 2017];

Available

from: https://en.wikipedia.org/w/index.php?title=Mapuche_language\&oldid=8118585 04.

45. Sotomayor, C., et al., Competencias lingüísticas e interculturales de los educadores tradicionales mapuche para la implementación de la asignatura de Lengua Indígena en Chile. 2015, Centro de Investigacion Avanzada en Educacion - Universidad de Chile: Chile. p. 34.

46. Quintriqueo, S. and H. Torres, Construcción de Conocimiento Mapuche y su relación con el Conocimiento Escolar. Estudios pedagógicos (Valdivia), 2013. 39, No. 1: p. 199-216. 
47. Forno, A.-S. and R.P. Rivera, Entre El Edificio y El Curriculum de la Interculturalidad - Una Mirada Antropologica a la Educacion Actual en Territorio Mapuche-Huilliche. Chungara. Revista de Antropologia Chilena, 2009. 41(2): p. 287-298.

48. Miller, A. La Falta de Desarrollo Debido a la Carencia de Igualdad: La Ineficacia del Programa de Educación Intercultural Bilingüe Como Factor de Continuación de la Dominación del Estado de Chile Contra el Pueblo Mapuche. Independent Study Project (ISP) Collection, 2012.

49. Quintriqueo, S. and H. Torres Distancia entre el conocimiento mapuche y el conocimiento escolar en contexto mapuche. Revista Electrónica de Investigación Educativa, 2012. 14, 16-33.

50. Quilaqueo, D., et al., Saberes Educativos Mapuches: Aportes Epistemicos Para Un Enfoque De Educacion Intercultural. Chungara. Revista de Antropologia Chilena, 2014. 46(2): p. 271-283. 